И.Н. ЗАХАРОВА ${ }^{1}$, И.В. БЕРЕЖНАЯ ${ }^{1,2}$, Т.Н. САННИКОВА ${ }^{2}$ Ж.Х. МАЛКАНДУЕВА ${ }^{3}$, А.Е. КУЧИНА ${ }^{1,3}$, Ю.О. САЗАНОВА ${ }^{1}$, О.В. ДЕДИКОВА ${ }^{1}$, К.А. КОЛЬЦОВ ${ }^{1}$

1 ФГБОУ ДПО «Российская медицинская академия непрерывного профессионального образования» Минздрава России, Москва

2 Химкинская центральная клиническая больница, отделение педиатрии

3 ГБУЗ МО «Красногорская городская больница №2, детская поликлиника №3»

\title{
KECAPEBO CEЧЕНИЕ
}

\section{И ПРОБЛЕМЫ ЛАКТАЦИИ У ЖЕНЩИН}

К сожалению, не каждая молочная железа функционирует в полном объеме, выполняя свою основную функцию - продукцию молока для кормления младенца. Чаще это связано с техническими ошибками при вскармливании ребенка, в результате чего могут появляться трещины, мацерация сосков, и женщины прекращают грудное вскармливание. Одна из наиболее частых проблем, встречающихся при естественном вскармливании, - лактостаз. В статье освещены вопросы физиологии лактации, обсуждаются проблемы, возникающие при лактации, факторы риска развития гипогалактии, а также приведены правила использования молокоотсосов для поддержания лактации.

Ключевые слова: дети, грудное молоко, лактация, проблемы, возникающие при лактации, лактостаз, кесарево сечение, грудное вскармливание.

\section{I.N. ZAKHAROVA ${ }^{1}$, I.V. BEREZHNAYA ${ }^{1,2}$, T.N. SANNIKOVA ${ }^{2}$, Z.H. MALKANDUEVA ${ }^{3}$, A.E. KUCHINA ${ }^{1,3}$, YU.O. SAZANOVA ${ }^{1}$, O.V. DEDIKOVA ${ }^{1}$, K.A. KOLTSOV ${ }^{1}$ \\ ${ }^{1}$ Russian Medical Academy of Continuing Postgraduate Education of the Ministry of Health of Russia, Moscow, Russia \\ 2 Khimki Central Clinical Hospital, Paediatrics Department, Khimki, Russia \\ ${ }^{3}$ Krasnogorsk City Hospital No. 2, Children's Clinic No. 3, Krasnogorsk, Russia \\ CAESAREAN SECTION AND LACTATION PROBLEMS IN WOMEN}

Unfortunately, not every mammary gland functions in full when fulfils its main function, which is milk production for infant feeding. Most often, the technical errors during breastfeeding the baby cause nipple cracks, maceration and women stop breastfeeding. Engorgement is one of the most common problems faced during natural breastfeeding. The article highlights the issues of the physiology of lactation, discusses the problems arising during lactation, the risk factors for the development of hypogalactia, and describes the rules for using breast pumps to maintain lactation.

Keywords: children, breast milk, lactation, problems arising during lactation, engorgement, cesarean section, breastfeeding.

настоящее время, с учетом появления и внедрения в практику современных методов исследования, позволивших открыть новые компоненты грудного молока, интерес к его составу и влиянию на здоровье человека растет с каждым годом. К сожалению, не каждый ребенок имеет возможность получать грудное молоко в достаточном объеме. По данным ретроспективного опроса женщин о причинах раннего прекращения грудного вскармливания оказалось, что уже через 1-3 мес. две трети из них отказывались кормить младенца грудью. При этом 90\% из них сразу после родов хотели сохранить грудное вскармливание до 1,5 года [1].

Проблема раннего перевода на искусственное вскармливание актуальна для многих стран, особенно индустриально развитых. Например, исследование, проведенное в США, в которое было включено 1799 беременных женщин, показало, что до родов большинство из них хотели кормить младенцев грудью в течение продолжительного времени, однако только 34\% кормили до 3 мес. и только 9\% - до 6 мес. В группе грудного вскармливания до 3 мес. около половины женщин (46\%) оценивали исключительно грудное вскармливание как необходимое и очень ценное, что позволяло сохранить его до 6 мес. [2].

Самые частые причины отказа матери от грудного кормления в России - это трещины и мацерация сосков, лактостаз, усталость матери. Американская ассоциация педиатров указывает на несколько других аспектов ран- него прекращения грудного вскармливания в США. Первый - недостаточное внимание государства к проблеме раннего отказа от грудного вскармливания в качестве проблемы общественного здравоохранения [3]. Второй - недооценка обществом важности продолжительности исключительно грудного вскармливания [4, 5]. Третий - неадекватные исследования, касающиеся исключительно грудного вскармливания, в США [6].

Как видно из отчета Федеральной службы государственной статистики России, количество младенцев, получающих естественное вскармливание на первом году жизни, к сожалению, не растет (рис.). В Российской Федерации за последние 20 лет грудное вскармливание до 6 мес. жизни получают менее 50\% младенцев, а это самый важный возрастной период для формирования здоровья ребенка.

\section{КЛЮЧЕВЫЕ АСПЕКТЫ НЕОБХОДИМОСТИ ГРУДНОГО ВСКАРМЛИВАНИЯ}

A.

1. Продолжительность грудного вскармливания прямо пропорциональна частоте инфекционной патологии у младенцев, в т. ч. и в отдаленной перспективе. В систематических обзорах показаны более низкая инфекционная заболеваемость и смертность у детей, длительно вскармливаемых грудью. 
2. Естественное вскармливание оказывает благотворное влияние на развитие жевательного аппарата ротовой полости, прикуса, что в дальнейшем способствует формированию речи.

3. Более короткие периоды грудного вскармливания негативно влияют на интеллект младенца, что имеет тенденцию к сохранению в течение всей жизни.

4. Естественное вскармливание оказывает влияние на метаболизм младенца, короткая его продолжительность способствует развитию ожирения в дальнейшем.

Б. Доказано, что продолжительное грудное вскармливание обладает протективным эффектом в плане защиты женщин от рака молочной железы, яичников, увеличивает интервал между последующими родами, снижает риск развития сахарного диабета 2-го типа.

B. В странах со стабильной экономикой и развитой индустрией продолжительность грудного вскармливания значительно меньше, чем в слаборазвитых странах и в странах со средним экономическим уровнем. Однако, по данным систематического обзора, показано, что только 37\% детей получают исключительно грудное вскармливание до 6 мес. даже в странах с низким и средним уровнем доходов.

г. Соблюдение рекомендаций ВОЗ по грудному вскармливанию может предотвратить детскую смертность примерно в 823 тыс. случаев и смертельные исходы от рака молочной железы у 20 тыс. женщин.

д. Новые методы исследования состава грудного молока и его микробиома доказывают, что грудное молоко можно расценивать как персонализированное питание для вскармливания конкретной матерью конкретного младенца.

E. На сегодняшний день содействие грудному вскармливанию во всех странах мира может способствовать увеличению продолжительности жизни и снижению заболевамости, что значимо уменьшит экономические издержки для здравоохранения.

\section{Количество младенцев, получающих естественное вскармливание на первом году жизни, к сожалению, не растет. В Российской Федерации за последние 20 лет грудное вскармливание до 6 мес. жизни получают менее $50 \%$ младенцев, а это самый важный возрастной период для формирования здоровья ребенка}

Известно, что частота респираторных и аллергических заболеваний значимо выше у детей, не получавших грудное молоко с рождения или получавших непродолжительно, что способствует развитию хронических заболеваний, приводит к значительным экономическим издержкам [8]. В исследовании И.П. Матвеевой с соавт. (2016) показано, что младенцы, получавшие искусственное вскармливание обычной молочной формулой, достоверно чаще страдали респираторными инфекциями, осложненными острым бронхитом, отитом, а также инфекцией мочевых путей, по сравнению с группой младенцев,

\section{Рисунок. Частота грудного вскармливания в России за 20 лет по данным Федеральной службы государственной статистики [7]}

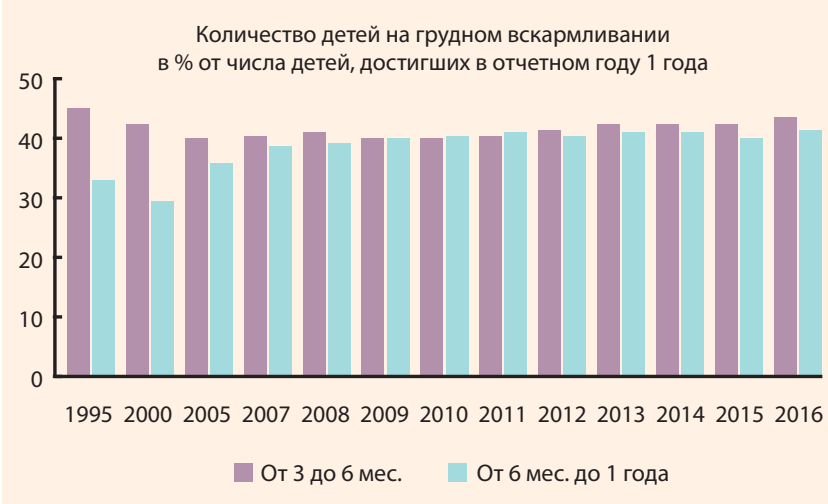

вскармливаемых грудью [9, 10]. В США подсчитали, что если 90\% женщин будут придерживаться рекомендаций ВО3 по исключительно грудному вскармливанию ребенка до 6 мес., то страна сэкономит около 13 млрд долл. на нужды здравоохранения в год и спасет 911 младенческих жизней [11].

Банки грудного молока начали создавать еще в прошлом веке. Например, в Норвегии в 1992 г. больницы платили по 50 долл. за 1 л грудного молока и собрали 8,2 млн л ценой 410 млн долл. за 1 год. То есть уже 30 лет назад отношение к грудному вскармливанию в мире кардинально изменилось, начались серьезные исследования не только его состава, но и влияния продолжительности естественного вскармливания на здоровье поколений в дальнейшем. В США в 2010 г. банки грудного молока платили 3-5 долл. за 30 мл грудного молока [12].

По сравнению с прошлым веком изменились и рекомендации по грудному вскармливанию. Так, эксперты ВОЗ рекомендуют не только обязательно приложить младенца к груди на родовом столе, но и продолжать грудное вскармливание после 6 мес., вплоть до 2 лет [13]. В исследованиях, проведенных М.Т. Perrin с соавт. (2016) из Университета Северной Каролины, продемонстрировано, что вскармливание ребенка грудным молоком на втором году жизни вовсе не является «вредной привычкой» малыша. Результаты исследований показывают, что «старое» молоко не уступает по своей пользе и ценности более «молодому». Доказано, что грудное молоко женщин на сроках с 11-го по 17-й мес. лактации более богато белком, лактоферрином, лизоцимом, иммуноглобулином A, натрием, олигосахаридами по сравнению с молоком в более ранние сроки [14]. Это подтверждают результаты ранее проведенных исследований, свидетельствующих о том, что грудное молоко «подстраивается» под потребности растущего ребенка [10].

На сегодняшний день очень мало данных о влиянии продолжительного (более 1,5 года) грудного вскармливания на состояние здоровья детей. В базе данных Medline найдено только 7 статей на эту тему, авторы 5 из них - из развивающихся стран, и только в 2-х проведена оценка 
Таблица 1. Состав грудного молока в сроке лактации 12-23 месяца

\begin{tabular}{l|c}
\multicolumn{1}{c|}{ Ингредиенты } & $\begin{array}{c}\text { 448 мл грудного молока } \\
\text { обеспечивают сугочную потребность }\end{array}$ \\
\hline Белок & $43 \%$ \\
\hline Кальций & $36 \%$ \\
\hline Витамин А & $75 \%$ \\
\hline Фолиевая кислота & $76 \%$ \\
\hline Витамин $\mathrm{B}_{12}$ & $94 \%$ \\
\hline Витамин С & $60 \%$ \\
\hline
\end{tabular}

*Энергетическая ценность 448 мл грудного молока в сроке лактации 12-23 мес. составляет $29 \%$ суточной потребности.

состава грудного молока у женщин, кормивших детей более 1,5 года [15]. В работах показано, что всего 448 мл грудного молока на сроке лактации 12-23 мес. обеспечивают суточную потребность ребенка в энергии на 30\%, в белке - более чем на 40\% (табл. 1) [15, 16]. В некоторых исследованиях указано, что энергетические потребности ребенка покрываются за счет молочного жира, доля которого достигает 28\% [15]. Долгосрочные эффекты такого высокого потребления жиров не изучались, как и их качественный состав. Известно, что в грудном молоке по сравнению с детской смесью намного больше холестерина и насыщенных жиров [17].

В медицинской литературе немало работ, посвященных вопросам лактации и факторам, влияющим на здоровье младенца. Большинство из них освещают социальные вопросы, психологический настрой, готовность женщины к материнству, основываясь на работах И.А. Аршавского о доминанте лактации [18]. Анкетирование 700 женщин с целью выяснения причин, почему не всегда эффективна главная функция молочных желез - лактация, показало, что участницы опроса придавали большое значение поддержке семьи, необходимости рационального питания, правильному и частому прикладыванию ребенка к груди и даже сцеживанию грудного молока, а вот интерес женщин к вопросам физиологии лактации невелик [1]. Между тем недостаточная осведомленность или нежелание получения знаний о пользе грудного молока, способах поддержания лактации и ухода за молочной железой одно из препятствий на пути к здоровому вскармливанию [19]. К сожалению, в некоторых женских консультациях школы матерей проводятся формально, получаемая информация недостаточна, что заставляет будущих мам получать недостоверную информацию из Интернета. До 1960-х гг. женщины с недостаточным образованием и низким уровнем доходов имели большее желание кормить младенца грудью как можно дольше. Однако сегодня в исследованиях показано, что образованность и высокие цифры коэффициента интеллекта IQ матери также повышают шансы малыша на естественное вскармливание, т. к. эти женщины выбирают научную информацию, а не форумы [20-21]. Авторы делают выводы, что длительное грудное вскармливание младенца способствует в дальнейшем большим успехам в обучении и финансовой независимости в старшем возрасте [22, 23]. В некоторых работах показано, что продолжительное грудное вскармливание формирует челюстно-лицевой аппарат и правильный прикус не только у ребенка с молочными зубами, но и сохраняет эту тенденцию у взрослых. Однако в других работах показано, что грудное вскармливание более 12 мес. и ночное кормление ассоциированы с 2-3-кратным увеличением риска кариеса, возможно, из-за нарушения гигиены полости рта [24].

\section{ФИЗИОЛОГИЯ ЛАКТАЦИИ}

Лактация включает несколько стадий: маммогенез, первую и вторую стадии лактогенеза и галактопоэз, которые имеют многоступенчатую гормональную регуляцию $[19,25]$. Лактогенез и галактопоэз являются неотъемлемой частью процесса завершения дифференцировки тканей молочной железы. А значит, продукция молока необходима женщине не меньше, чем ребенку! Молочная железа во время беременности подвергается структурнофункциональным изменениям: в I триместре формируется дольчато-ячеистая структура, а в середине II триместра стартует первая стадия лактогенеза, когда эпителиоциты альвеол трансформируются в лактоциты и начинается продукция молозива (табл. 2) [19].

Понятно, что становление лактационной функции у женщин зависит не только от сформированной доминанты лактации, но и от нормального течения беременности

\section{Таблица 2. Физиологические основы лактации [19]}

\begin{tabular}{|c|c|c|c|}
\hline & Первая стадия лактогенеза & Вторая стадия лактогенеза & Галактопоэз \\
\hline Продолжительность & $\begin{array}{l}\text { С середины II триместра до 2-3-го дня } \\
\text { после родов }\end{array}$ & $\begin{array}{l}\text { Во время родов - до 7-8-го дня после } \\
\text { родов }\end{array}$ & $\begin{array}{l}\text { C 7-8-го дня после родов до инволюции } \\
\text { лактации }\end{array}$ \\
\hline Значение & Стартует секреция молозива & Выработка и выделение молока & Установившаяся лактация \\
\hline Основные этапы & $\begin{array}{l}\text { - Дифференцировка эпителиоцитов в } \\
\text { лактоциты, секретирующие молозиво } \\
\text { - Кортизол (гормон стресса), выделяе- } \\
\text { мый при физиологических родах, спо- } \\
\text { собствует образованию рецепторов } \\
\text { пролактина в молочной железе }\end{array}$ & $\begin{array}{l}\text { - Отделение плаценты ведет к резкому } \\
\text { падению в крови уровня прогестерона } \\
\text { и эстрогенов } \\
\text { - Выброс пролактина } \\
\text { - Контакт «кожа с кожей» - переключение } \\
\text { эндокринной регуляции на аутокринную }\end{array}$ & $\begin{array}{l}\text { Характеризуется аутокринной регуляцией } \\
\text { («по надобности») и рефлекторным меха- } \\
\text { низмом выделения молока }\end{array}$ \\
\hline
\end{tabular}


и родов. Экстрагенитальная патология, патологические роды, роды путем кесарева сечения могут способствовать угнетению лактационной функции. Так, одним из наиболее частых осложнений беременности является гестоз. По данным Росстата, в 2016 г. 8,4\% рожениц имели гестоз, проявлявшийся отеками, артериальной гипертензией и протеинурией [26]. Тяжесть гестоза коррелирует с недостаточной суточной секрецией грудного молока, малой выработкой гипофизарных гормонов (окситоцина и пролактина), что способствует снижению лактации. Показано, что у женщин, перенесших тяжелый гестоз, уровень пролактина к 6-му дню после родов на 72,6\% ниже, чем у родильниц с нормально протекавшей беременностью и физиологическими родами [27]. У женщин после планового кесарева сечения отмечаются выраженные нарушения эндокринной регуляции лактации, секреции и выделения молока, что усугубляется в случаях, если беременность протекала с гестозом [28]. Плановое кесарево сечение не способствует нормальному физиологическому стрессу матери и ребенка, который необходим для адаптации к новым условиям существования. По данным В.Е. Радзинского (2017), имеет место прямо пропорциональная зависимость вероятности и продолжительности исключительно грудного вскармливания от момента контакта младенца с матерью сразу после рождения [19]. Известно, что для младенца запах околоплодных вод и запах молозива идентичны. Поэтому прикладывание малыша к груди матери на родовом столе необходимо не только с физиологической, но и с психологической точки зрения [26]. По данным систематического обзора исследований, проведенных в 33 странах мира, прослеживается прямая связь между плановыми оперативными родами и коротким периодом грудного вскармливания (табл. 3) [30].

\section{Известно, что для младенца запах околоплодных вод и запах молозива идентичны. Поэтому прикладывание малыша к груди матери на родовом столе необходимо не только с физио- логической, но и с психологической точки зрения}

На сегодняшний день значительно расширены показания к проведению планового кесарева сечения, частота его проведения растет, операции проводятся не только по медицинским показаниям, но и по желанию матери. Например, в некоторых странах Латинской Америки на долю кесарева сечения приходится до 56\% родов [33]. В России, по данным Росстата, имеет место рост частоты кесарева сечения - с 17,9\% в 2005 г. до 28\% к 2016 г. [26].

Как сохранить лактацию? На сегодняшний день, несмотря на обилие информации, все женщины нуждаются в поддержке и обучении навыкам ухода за младенцем и грудного вскармливания. Особенно это важно после планового родоразрешения, т. К. именно эта группа родильниц не имеет достаточной физиологической и психологической мотивации к грудному вскармливанию. Консультирование женщин по вопросам питания, грудно-

\section{Таблица 3. Влияние планового кесарева сечения на становление лактации}

\begin{tabular}{l|l}
\hline \multicolumn{1}{c|}{$\begin{array}{l}\text { Отсутствует физиологический } \\
\text { процесс отслоения плаценты }\end{array}$} & $\begin{array}{l}\text { Торможение выработки молока - } \\
\text { удлинение сроков становления } \\
\text { лактации }\end{array}$ \\
\hline $\begin{array}{l}\text { Зачастую невозможен контакт } \\
\text { матери и ребенка сразу после } \\
\text { родов (прикладывание новорож- } \\
\text { денного к груди) }\end{array}$ & $\begin{array}{l}\text { Угнетение окситоцинового рефлек- } \\
\text { са при отсутствии сосания }\end{array}$ \\
\hline Эпидуральная анестезия & $\begin{array}{l}\text { Угнетение синтеза окситоцина } \\
\text { после родов [31] }\end{array}$ \\
\hline $\begin{array}{l}\text { Высокий уровень кортизола (гор- } \\
\text { мон стресса) в ответ на оператив- } \\
\text { ное вмешательство }\end{array}$ & $\begin{array}{l}\text { Торможение наступления второй } \\
\text { стадии лактогенеза [19] }\end{array}$ \\
\hline $\begin{array}{l}\text { Низкий сосательный рефлекс у } \\
\text { детей, рожденных путем кесарева } \\
\text { сечения }\end{array}$ & $\begin{array}{l}\text { Удлинение срока становления лак- } \\
\text { тационной функции и сокращение } \\
\text { длительности лактации [32] }\end{array}$ \\
\hline
\end{tabular}

го вскармливания, назначение препаратов для стимуляции лактации, физиолечение снижают частоту случаев гипогалактии у женщин после планового кесарева сечения. Двухлетнее исследование, проведенное учеными из Таджикского государственного медицинского университета им. Абуали ибни Сино показало, что реабилитация и диспансеризация женщин после абдоминального родоразрешения снижают число осложнений и отказ от грудного вскармливания на 4,34\% против $12,5 \%$ в группе контроля [34].

Очень важно прикладывать ребенка к груди правильно: - поза во время кормления должна быть удобна как для матери, так и для ребенка;

- туловище и голова ребенка должны быть в одной плоскости;

- рот ребенка должен быть широко открыт для захвата не только соска, но и ареолы, важно следить за тем, чтобы ребенок захватывал сосок со стороны подбородка больше, чем со стороны носа $[19,35]$.

Обучение женщины технике грудного вскармливания профилактирует лактостаз и образование трещин сосков, т. е. позволяет избежать воспаления и условий для развития мастита. Обеспечить хороший отток молока при лактостазе можно, принимая различные позы во время кормления ребенка, что улучшает отток молока в верхней и/или нижней долях молочной железы. Одним из эффективных средств борьбы с лактостазом является массаж (легкий перед кормлением или терапевтический), который также обеспечит хороший отток молока и лимфодренаж. Ученые из Китая в исследовании показали достоверное положительное действие массажа молочной железы у 80 женщин после кесарева сечения на выработку пролактина: 195,9 \pm 78,5 мкг/л против 128,8 \pm 40,6 мкг/л ( 0,007). Сцеживание грудного молока после кормления также эффективное средство борьбы с лактационным маститом [19, 36].

Сцеживание - самый простой и издревле известный способ профилактики лактостаза и сохранения лактации. 
Таблица 4. Основные рекомендации по поддерживанию грудного вскармливания

\begin{tabular}{|c|c|c|}
\hline Факторы & Влияние на лактацию & Примечание \\
\hline Течение беременности & $\begin{array}{l}\text { Гестоз I и II триместров беременности. Тяжесть его прямо про- } \\
\text { порциональна гипогалактии. Уже в I триместре образуется доль- } \\
\text { чато-ячеистая структура, в середине II триместра стартует первая } \\
\text { стадия лактогенеза, когда эпителиоциты альвеол трансформиру- } \\
\text { ются в лактоциты и начинается продукция молозива }[19,46]\end{array}$ & $\begin{array}{l}\text { Тяжелый гестоз снижает уровень пролактина у женщин к 6-му } \\
\text { дню после родов на } 72,6 \% \text { по сравнению с таковым у женщин с } \\
\text { нормально протекавшими физиологическими родами }[26,27]\end{array}$ \\
\hline $\begin{array}{l}\text { Плановое кесарево } \\
\text { сечение }\end{array}$ & $\begin{array}{l}\text { Отсутствие физиологического стресса матери и ребенка, нару- } \\
\text { шение адаптации [19] }\end{array}$ & \\
\hline \multicolumn{3}{|c|}{ Меры профилактики гипогалактии } \\
\hline $\begin{array}{l}\text { Раннее прикладывание } \\
\text { младенца к груди (на } \\
\text { родовом столе) }\end{array}$ & $\begin{array}{l}\text { Известно, что для младенца запах околоплодных вод и запах } \\
\text { молозива идентичны. Поэтому прикладывание малыша к груди } \\
\text { матери на родовом столе необходимо не только с физиологи- } \\
\text { ческой, но и с психологической точки зрения [29] }\end{array}$ & $\begin{array}{l}\text { По данным В.Е. Радзинского (2017), имеет место прямо про- } \\
\text { порциональная зависимость вероятности и длительности } \\
\text { исключительно грудного вскармливания от длительности кон- } \\
\text { такта младенца с матерью сразу после рождения [19] }\end{array}$ \\
\hline $\begin{array}{l}\text { Массаж молочной } \\
\text { железы }\end{array}$ & $\begin{array}{l}\text { Массаж (легкий перед кормлением или терапевтический), } \\
\text { который обеспечит хороший отток молока и лимфодренаж }\end{array}$ & $\begin{array}{l}\text { Ученые из Китая в исследовании показали достоверный поло- } \\
\text { жительный эффект массажа молочной железы у } 80 \text { женщин } \\
\text { после кесарева сечения на выработку пролактина: } 195,9 \pm \\
78,5 \text { мкг/л против 128,8 } 4 \text { 40,6 мкг/л (p = 0,007). Сцеживание } \\
\text { грудного молока после кормления - также эффективное сред- } \\
\text { ство борьбы с лактационным маститом [36] }\end{array}$ \\
\hline $\begin{array}{l}\text { Позы при } \\
\text { вскармливании } \\
\text { младенца для } \\
\text { уменьшения лактостаза }\end{array}$ & $\begin{array}{l}\text { Обеспечить хороший отток молока при лактостазе можно раз- } \\
\text { личными позами во время кормления ребенка }\end{array}$ & $\begin{array}{l}\text { Поза «валетом» («69») поможет при застойных явлениях в } \\
\text { верхних долях молочной железы. } \\
\text { Поза «футбольный мяч», когда ребенок расположен под мыш- } \\
\text { кой у матери головой вперед, устранит застой молока в доба- } \\
\text { вочных дольках железы и хороша для женщин после оператив- } \\
\text { ных родов, т. к. исключено давление на брюшную стенку [19] }\end{array}$ \\
\hline $\begin{array}{l}\text { Психологическая } \\
\text { поддержка }\end{array}$ & $\begin{array}{l}\text { Недостаточная самооценка матери, особенно при преждевре- } \\
\text { менных родах, чувство вины. Дополнительное сцеживание } \\
\text { молока приводит к улучшению психологического состояния } \\
\text { матери [47] }\end{array}$ & $\begin{array}{l}\text { Школы поддержки грудного вскармливания, использование } \\
\text { современных молокоотсосов, семейный психолог помогают } \\
\text { не только сохранить грудное молоко, но и улучшить климат в } \\
\text { семье [10] }\end{array}$ \\
\hline
\end{tabular}

Оно особенно важно при ослабленном сосании младенца или невозможности совместного пребывания в палате матери и ребенка, особенно в группах риска [37]. Ручной способ сцеживания не всегда удобен и далек от физиологии молоковыведения. Ученые в течение десятилетий изучали физиологию и совершенствовали методики массажа и ручного сцеживания. После появления механических приспособлений для сцеживания грудного молока возникло множество споров о том, что эффективнее для лактации и безопаснее для молочной железы. Одно из исследований показало, что у матерей, родивших раньше срока, но рано начавших сцеживание с частотой не менее 6 раз в сутки, объем грудного молока был значительно больше, чем при сцеживании менее 6 раз в сутки. Авторы отмечают, что осложнений меньше, а объем молока больше при использовании механического молокоотсоса, чем при ручном сцеживании, при равных количествах сцеживания в сутки [38].

Впервые молокоотсос запатентован О.Н. Нидхамом в США в 1854 г., через 9 лет в России Л.О. Колбин предложил свой вариант молокоотсоса. Только в 1920 г. был запатентован и стал применяться механический молокоотсос, изобретенный Э. Ласкером. А в середине XX в. появились стационарные молокоотсосы, что позволило уже на самых ранних этапах после родов использовать их для сохранения лактации [39]. Наибольший интерес к молокоотсосам пришелся на вторую половину XX в. Используя аппараты, учитывающие амплитудные и временные соотношения стимулов вакуума и сжатия, датчики давления, пневмокамеры, ученые пришли к выводу, что воздействие ребенка на ареолу периодично и характеризуется разным уровнем давления и, соответственно, количеством выделенного молока. Период состоит из пиков (тактильное сжатие) и пауз, при этом в первые 4-5 мин сосания количество пиков превышает количество пауз, в дальнейшем их отношение меняется [40,41]. В XXI в. была сформирована математическая модель сосания [42]. Это помогло не только создать правильный физиологичный режим для моделирования физиологии сосания при использовании молокоотсоса, но и продумать особенности сосок для детей на искусственном вскармливании. В исследованиях показано, что у детей на искусственном вскармливании в $15 \%$ случаев чаще формируются зубочелюстные аномалии. Это еще раз подчеркивает важность того, что именно сосание младенцем груди формирует соматическое и психологическое здоровье ребенка [42].

Данные, полученные учеными при изучении механики процесса выделения молока, соответствуют процессу гормональной регуляции - «окситоциновому рефлексу», т. е. пик скорости выделения молока соответствует выбросу окситоцина в кровь кормящей матери, а значит, молокоотсосы формируют полноценные рефлексы молокоотдачи $[40,43]$. Дальнейшее изучение силы давления (вакуума) для эффективного сцеживания молока привело к созданию электрических аппаратов с возможностью самостоя- 
тельной регулировки силы давления, комфортной для каждой матери индивидуально. При этом комфортная сила давления при 15-минутном сцеживании соответствовала большему объему молока и его большей жирности [44]. Среди современных молокоотсосов хотелось бы отметить электронные молокоотсосы для стационарного применения (например, Symphony (Medela)). Раннее начало использования молокоотсоса, особенно у женщин из группы риска (плановое кесарево сечение, роды раньше срока, патологическая беременность и др.), способны «запустить» лактацию. Клинические молокоотсосы Medela обладают особой программой поддержки, имитируя особый ритм сосания младенца в первые дни после родов. Это достигается за счет комбинации из разных режимов стимуляции с высокой цикличностью и низким уровнем вакуума. Опорожнение молокоотсосом молочной железы при отсутствии возможности у ребенка сосать грудь сразу после рождения (отлучение от матери, вялое сосание) способствует запуску второй стадии лактогенеза. Молокоотсос Symphony максимально физиологичен, учитывает ритмы сосания и режимы стимуляции, а двойное сцеживание увеличивает объем выделенного молока на 18\% [45].

Для современной женщины, имеющей плотный рабочий график, насыщенную общественную жизнь, беременность, роды, особенно преждевременные и/или оперативные, являются серьезным стрессом, и не все женщины к этому готовы. Поэтому рекомендации по поддержке грудного вскармливания включают не только советы по подготовке молочной железы к физиологическим трудностям, обучение технике правильного прикладывания ребенка к груди, информацию о способах профилактики трудностей лактации, но и серьезную психологическую поддержку семьи (табл. 4). Для беременных женщин важно проводить разъяснения и подчеркивать важность родов естественным путем, а не путем кесарева сечения, кажущегося «более удобным и безболезненным». Убедить мать на первом патронаже кормить ребенка грудью первый шаг врача-педиатра к профилактике детской заболеваемости и смертности. Это путь к сокращению затрат на медицинское обеспечение, а значит, и к экономическому благосостоянию государства.

\section{ЗАКЛЮЧЕНИЕ}

Грудное молоко - незаменимая «живая ткань» для вскармливания младенца и формирования его здоровья в будущем. Многочисленные исследования показали, что, несмотря на новейшие технологии в пищевой отрасли, воссоздать полный аналог грудного молока невозможно. Меры профилактики должны применяться уже на этапе планирования беременности, т. к. патологически протекающая беременность является значимым фактором риска гипогалактии. Сразу после рождения малыша необходимо использовать весь арсенал средств для стимуляции лактации и обучения молодой матери правильному прикладыванию к груди, для ухода за грудью, сохранения

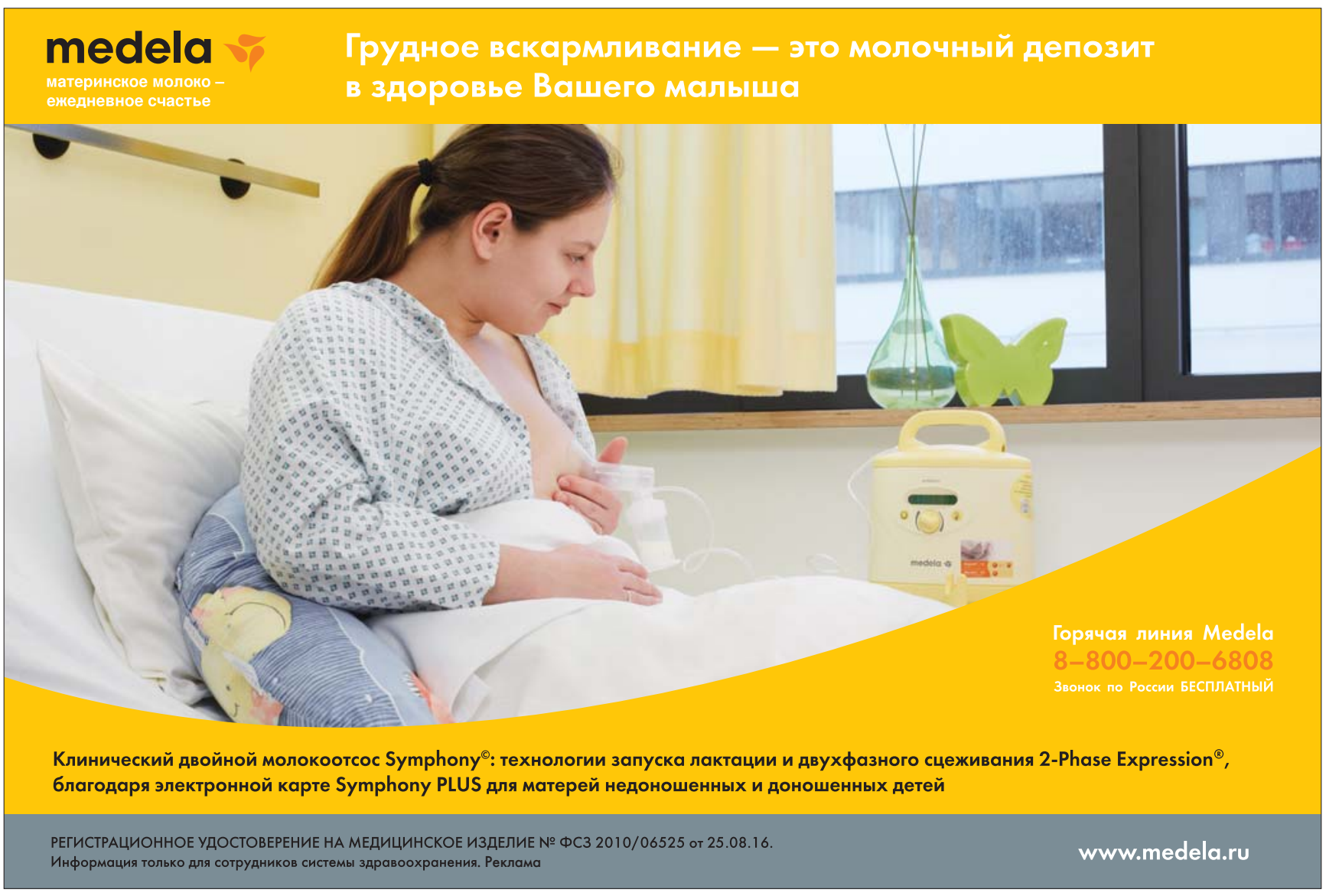


грудного вскармливания как можно дольше. Одним из профилактических средств на самых ранних этапах является использование молокоотсосов, в первые дни после родов - стационарных, далее - индивидуальных портативных. Обучение молодой матери использованию молокоотсоса в роддоме поможет ей справиться с этим в домашних условиях, окажет незаменимую помощь в сохранении грудного вскармливания и позволит избежать осложнений, связанных с лактостазом и маститом.

Основные рекомендации по поддержке грудного вскармливания:

1. Психологическая поддержка молодой матери семьей и родовспомогательными учреждениями.

2. Раннее прикладывание ребенка к груди (на родовом столе).
3. Совместное пребывание матери и ребенка в послеродовом отделении.

4. Правильное прикладывание ребенка к груди, что позволит избежать появления трещин и лактостаза.

5. Кормление по требованию, в т. ч. ночные кормления.

6. Массаж молочной железы, который можно рекомендовать уже через 2 ч после операции (повторить через 12, 24, 48, 72 ч после родов).

7. Сцеживание грудного молока позволит инициировать, поддержать и пролонгировать лактацию.

8. Единственный возможный путь естественного вскармливания - вскармливание ребенка грудью матери.

Конфликт интересов: авторы заявляют об отсутствии конфликта интересов в ходе написания данной статьи.

\section{ЛИТЕРАТУРА}

1. Строева Л.Е., Мозжухина Л.И., Калгина С.Е., Ратынская Н.В., Горячева Н.Ю. Почему не всегда эффективна главная функция молочных желез - лактация (анализ результатов анкетирования 744 кормящих грудью матерей). II Национальный конгресс «Онкология репродуктивных органов: от профилактики и раннего выявления к эффективному лечению», 11-13 мая 2017 года, Москва. Исследования и практика в медицине, 2017, 2: 87. /Stroeva LE, Mozzhukhina LI, Kalgina SE, Ratynskaya NV, Goryacheva NYu. Why the main function of the mammary glands - lactation is not always effective (outcome analysis of the questionnaire survey of 744 breastfeeding mothers). The $2^{\text {nd }}$ National Congress "Oncology of the reproductive organs: from prevention and early detection to effective treatment", May 11-13, 2017, Moscow. Issledovaniya i Praktika v Meditsine, 2017, 2: 87.

2. Nnebe-Agumadu UH, Racine EF, Laditka SB, Coffman MJ. Associations between perceived value of exclusive breastfeeding among pregnant women in the United States and exclusive breastfeeding to three and six months postpartum: a prospective study. International Breastfeeding Journal, 2016, 11: 8. https: //doi. org/10.1186/s13006-016-0065-x.

3. CDC. Progress in increasing breastfeeding and reducing racial/ethnic differences - united states, 2000-2008 births. Morbidity Mortal Week Report, 2013, 62(5): 77-80.

4. Bai YK, Middlestadt SE, Joanne Peng CY, Fly AD. Psychosocial factors underlying the mother's decision to continue exclusive breastfeeding for 6 months: an elicitation study. J Hum Nutr Diet, 2009, 22(2): 134-140.

5. Labbok M, Taylor E. Achieving exclusive breastfeeding in the United States: findings and recommendations. Washington DC, United States: United States Breastfeeding Committee, 2008.

6. Baker S, Claeson M, Schultink W. Inside the politics of breastfeeding promotion. Impatient Optimists, 2014. Available at http: //www.impatientoptimists.org/Posts/2014/02/Inside-thePolitics-of-Breastfeeding-Promotion\#\#. Accessed 14 March 2015.

7. Федеральная служба государственной статистики, /Federal State Statistics Service http: // www.gks.ru/wps/wcm/connect/rosstat_main/ rosstat/ru/statistics/population/healthcare/\#.
8. Victora CG, Aluísio JD, Barros AJD, França GVA et al. Breastfeeding in the 21st century: epidemiology, mechanisms, and lifelong effect. Lancet, 2016, 387: 475-490.

9. Матвеева Е.В., Легонькова Т.И., Войтенкова О.В., Штыкова О.Н. Влияние различных видов вскармливания на соматическую и инфекционную заболеваемость детей первого года жизни. Вестник Смоленской государственной медицинской академии, 2016, 15(2): 32-35. Matveeva EV, Legonkova TI, Voitenkova OV, Shtykova ON. The impact of different types of feeding on the somatic and infectious morbidity of infants. Vestnik Smolenskoy Gosudarstvennoy Meditsinskoy Akademii, 2016 15 (2): 32-35.

10. Захарова И.Н., Османов И.М., Мачнева Е.Б., Бережная И.В., Кольцов К.А., Дедикова О.В., Кучина А.Е., Сазанова Ю.О., Мартыненко Л.Е. История грудного вскармливания: что препятствовало естественному способу питания младенцев от древних времен до современности? Медицинский совет, 2018, 11: 18-26./ Zakharova IN, Osmanov IM, Machneva EB, Berezhnaya IV, Koltsov KA, Dedikova OV, Kuchina AE, Sazanova YuO, Martynenko LE. The history of breastfeeding: what were the barriers to the natural way of feeding babies from ancient times to the modern era? Meditsinsky Sovet, 2018, 11: 18-26.

11. Bartick M, Reinhold A. The burden of suboptimal breastfeeding in the United States: a pediatric cost analysis. Pediatrics, 2010, 125(5): 1048-1056.

12. http: //mothering.com/ peggyomara/breastfeeding-2/the-economic-value-of-breast-milk

13. http: //www.who.int/ru/news-room/fact-sheets/ detail/infant-and-young-child-feeding.

14. Perrin MT, Fogleman AD et al. A longitudinal study of human milk composition in the second year postpartum: implications for human milk banking. Maternal and Child Nutrition, 2016, 13. http://dx.doi. org/10.1111/ mcn.12239.

15. Mandel D, Lubetzky R, Dollberg S, Barak S, Mimouni FB. Fat and Energy Contents of Expressed Human Breast Milk in Prolonged Lactation. Pediatrics, 2005, 116(3): 432-435.

16. Dewey KG, Finley DA, Lönnerdal B. Breast milk volume and composition during late lactation (7-20 months). J Pediatr Gastroenterol Nutr, 1984, 3(5): 713-720.
17. Giovannini M, Agostoni C, Riva E. Fat needs of term infants and fat content of milk formulae. Acta Paediatr. Suppl., 1994, 402: 59-62.

18. Гмошинская М.В. Факторы, влияющие на лактацию. Вопросы современной педиатрии, 2013, 12(2): 139-141. /Gmoshinskaya MV. Factors influensing lactation. Voprosy Sovremennoy Pediatrii, 2013, 12 (2): 139-141.

19. Радзинский В.Е. Медицина молочной железы и гинекологические болезни. 2-е изд., перераб. и доп. М.: Медиабюро StatusPraesens, 2017. 352 c. /Radzinsky VE. Breast medicine and gynecological diseases. $2^{\text {nd }}$ ed., updated and enlarged. M.: Mediabureau StatusPraesens, 2017. 352 p.

20. Batty GD, Der G, Macintyre S, Deary I. Does IQ explain socioeconomic inequalities in health? Evidence from a population based cohort study in the west of Scotland. BMJ, 2006, 332(7541): 580-584. doi: https: //doi.org/10.1136/ bmj.38723.660637.AE.

21. Rollins NC et al. Lancet Breastfeeding Series: Why invest, and what it will take to improve breastfeeding practices in less than a generation. Lancet, 2016, 387: 491-504.

22. Kim JI, Kim BN et al. Breastfeeding is associated with enhanced learning abilities in schoolaged children. Child Adolesc Psychiatry Ment Health, 2017, 11: 36. doi: 10.1186/s13034-0170169-0.

23. Victora CG, Horta BL, de Mola CL, Ouevedo L, Pinheiro RT, Gigante DP, et al. Association between breastfeeding and intelligence, educational attainment, and income at 30 years of age: a prospective birth cohort study from Brazil. Lancet Glob Health, 2015, 3(4): 199-205.

24. Victora CG, Bahl R, Barros AJD, França GVA, Horton S, Krasevec J, Rollins NC. Breastfeeding in the 21st century: Epidemiology, mechanisms, and lifelong effect. The Lancet, 2016, 387(10017): 475-490. doi: 10.1016/S01406736(15)01024-7.

25. Юрьев В.В. Пропедевтика детских болезней: учебник. Под ред. В.В. Юрьева, М.М. Хомича. М.: ГЭОТАР-Медиа, 2012.720 с./ Yuryev V. Propedeutics of childhood diseases: a guidebook. Under the editorship of Yuriev VV, Khomich MM. M.: GEOTAR-Media, 2012. 720 p.

26. Оксенойт Г.К., Никитина С.Ю., Агеева Л.И., Александрова Г.А. Зайченко Н.М., Кириллова Г.Н., Леонов С.А., Огрызко Е.В., Титова И.А., Харькова Т.Л., Чумарина В.Ж., Шубочкина Е.М. 
Здравоохранение в России. 2017: Стат. сб. Росстат. M., 2017. 170 с. /Oxenoyt GK, Nikitina SYu, Ageeva LI, Aleksandrova GA. Zaichenko NM., Kirillova GN, Leonov SA, Ogryzko EV, Titova IA, Kharkova TL, Chumarina VZh, Shubochkina EM. Health care in Russia. 2017: Stat. col. of Rosstat. M., 2017. 170 p.

27. Гутикова Л.В. Гормональная регуляция лактации у родильниц, перенесших гестоз. Журнал Гродненского государственного университеma, 2010, 1(29): 68-69. /Gutikova LV. Hormonal regulation of lactation in puerperas, who have had preeclampsia. Zhurnal Grodnenskogo Gosudarstvennogo Universiteta, 2010, 1 (29): 68-69.

28. Алиева Д.Х. Особенности лактации у родильниц после оперативного родоразрешения на фоне гестоза. Уральский медицинский журнал, 2007, 7: 109-112. / Aliyev DA. Features of lactation in puerperas after operative delivery against the background of preeclampsia. Uralsky Meditsinsky Zhurnal, 2007, 7: 109-112.

29. Тутельян В.А., Конь И.Я. Детское питание: Руководство для врачей 4-е изд., перераб. и доп. М.: Медицинское информационное агентство, 2017. 784 с. /Tutelyan VA, Kon IYa. Baby food: a guide for practitioners $4^{\text {th }}$ ed., updated and enlarged. M.: Medical Information Agency, 2017. 784 p.

30. Prior E, Santhakumaran S, Gale C, Philipps LH, Modi N, Hyde MJ. Breastfeeding after cesarean delivery: a systematic review and meta-analysis of world literature. Am J Clin Nutr, 2012, 95(5): 1113-1135. doi: 10.3945/ ajcn.111.030254.

31. Jonas W, Nissen E et al. Influence of oxytocin or epidural analgesia on personality profile in breastfeeding women: a comparative study. Archives of Women's Mental Health, 2008, 11(56): 335-345.

32. Zhang F, Yang Y, Bai T, Sun L, Sun M, Shi X, Zhu M, Ge M, Xia H. Effect of pumping pressure on onset of lactation after caesarean section: A randomized controlled study. Matern Child Nutr, 2018 Jan, 14(1). doi: 10.1111/mcn.12486. Epub 2017 Jul 27

33. http: //www.bbc.com/russian/science /2015/07/150721_c_sections_surgery_labour_vj.
34. Додхоева М.Ф., Юлдошева М.У. Реабилитация и диспансеризация женщин после абдоминального родоразрешения. Вестник Авиценны, 2016, 2(67): 42-47./ Dodkhoeva MF, Yuldosheva MU. Rehabilitation and prophylactic medical examination of women after abdominal delivery. Vestnik Avitseny, 2016, 2 (67): 42-47.

35. Захарова И.Н., Мачнева Е.Б. Грудное вскармливание: ответы на некоторые сложные вопросы кормящих женщин. Медицинский совет, 2017, 1: 60-65. /Zakharova IN, Machneva EB. Breastfeeding: answers to some difficult questions of breastfeeding women. Meditsinsky Sovet, 2017, 1: 60-65.

36. Chu JY, Zhang L, Zhang YJ, Yang MJ, Li XW, Sun LL. The effect of breast massage at different time in the early period after cesarean section. Zhonghua Yu Fang Yi Xue Za Zhi, 2017, 51(11): 1038-1040.

37. Грибакин С.Г., Лукоянова О.Л., Боровик Т.Э., Захарова И.Н., Скворцова В.А. Возможности сохранения лактации после преждевременных родов. Вопросы современной педиатрии, 2015, 14(5): 534-538. /Gribakin, SG, Lukoyanova OL, Borovik TE, Zakharova IN, Skvortsova VA. The possibility of preserving lactation after preterm labour. Voprosy Sovremennoy Pediatrii, 2015, 14 (5): 534-538.

38. Hill PD, Aldag JC, Chatterton RT. Effects of pumping style on milk production in mothers of non-nursing preterm infants. J Hum Lact, 1999, 15(3): 209-216.

39. Лукоянова О.Л., Боровик Т.Э., Беляева И.А., Яцык Г.В. Применение современных технологических приемов для сохранения успешного грудного вскармливания. Вопросы современной педиатрии, 2012, 11(5): 113-117. / Lukoyanova OL, Borovik TE, Belyaev IA, Yatsyk $\mathrm{GV}$. The use of modern technological methods to maintain successful breastfeeding. Voprosy Sovremennoy Pediatrii, 2012, 11 (5): 113-117.

40. Алексеев Н.П., Ярославский С.Н. и др. Роль вакуумных и тактильных стимулов в процессе выведения молока из молочной железы женщины. Физиологический журнал им. И.М. Сеченова, 1994, 80(9): 67-74. /Alekseev NP, Yaroslavsky SN, et al. The role of vacuum and tactile incentives in the process of removing milk from the mammal gland of women. Fiziologicheskiy Zhurnal im. I.M. Sechenova, 1994, 80 (9): 67-74.

41. Талалаева Н.Е. Механизмы формирования рефлексов выведения молока у родильниц: Автореф. дисс. ... канд. мед. наук. СПб., 2001, 18. Talalaeva NE. Mechanisms of formation of milk reflexes in puerperas: Author's abstract of $\mathrm{PhD}$ in medicine Dissertation. SPb, 2001, 18.

42. Булгакова М.И., Симановская Е.Ю., Няшин Ю.И., Тверье В.М. Биомеханика вскармливания детей раннего возраста. Российский журнал биомеханики, 2003, 7(4): 9-21. / Bulgakova MI, Simanovskaya EYu, Nyashin Yul, Tverye VM. Biomechanics of feeding young children. Rossiyskiy Zhurnal Biomekhaniki, 2003, 7 (4): 9-21

43. McNeilly AS, Robinson JCA, et al. Releaz of oxytocin and prolactin in response to sucking. Brit Med J, 1983, 286: 257-259.

44. Kent JC, Hartmann PE et al. Importance of vacuum for breastmilk expression. Breastfeeding Medicine, 2008, 3 (1): 11. First presented (2004) at the 12 th International conference of the International society for research in human milk and lactation. Cambridge, England.

45. Prime DK et al. Simultaneous breast expression in breastfeeding women is more efficacious than sequential breast expression. Breastfeed Med, 2012 Dec, 7(6): 442-447.

46. Агаркова Л.А., Габидулина Т.В., Габитова Н.А., Белова Н.Г. Влияние витаминно-минерального комплекса на становление лактации у женщин после физиологической и осложненной гестозом беременности. Российский вестник акушера-гинеколога, 2011, 5: 85-88. /Agarkova LA, Gabidulina TV, Gabitova NA, Belova NG. The effect of vitamin-mineral complex on the formation of milk in women after the physiological and gestosis-complicated pregnancy. Rossiyskiy Vestnik Akushera-Ginekologa, 2011, 5: 85-88.

47. Дуленков А.Б., Мухина Ю.Г., Потапова О.В. Грибакин С.Г. Особенности становления лактации у матерей после преждевременных родов. Вопросы практической педиатрии, 2011, 6(3): 64-69. /Dulenkov AB, Mukhina YuG, Potapova OV, Gribakin SG. Features of the formation of milk in mothers after preterm labor. Voprosy Prakticheskoy Pediatrii, 2011, 6 (3): 64-69.

\section{СВЕДЕНИЯ ОБ АВТОРАХ:}

Захарова Ирина Николаевна - доктор медицинских наук, профессор, заслуженный врач России, заведующая кафедрой педиатрии с курсом поликлинической педиатрии им. академика Г.Н. Сперанского ФГБОУ ДПО «Российская медицинская академия непрерывного профессионального образования» Минздрава России, член исполкома Союза педиатров России, полный член EAACI, ESPGHAN, Москва, Россия

Бережная Ирина Владимировна - кандидат медицинских наук, доцент кафедры педиатрии с курсом поликлинической педиатрии им. академика Г.Н. Сперанского ФГБОУ ДПО «Российская медицинская академия непрерывного профессионального образования» Минздрава России, Москва, Россия

Санникова Туйаара Николаевна - кандидат медицинских наук, заместитель главного врача по детству и родовспоможению Химкинской центральной клинической больницы Московской области, Химки, Россия

Малкандуева Жанетта Хусейновна - заведующая детской поликлиникой № 3 Красногорской городской больницы № 2 Московской области, Красногорск, Россия

Кучина Анастасия Евгеньевна - аспирант кафедры педиатрии с курсом поликлинической педиатрии им. академика Г.Н. Сперанского ФГБОУ ДПО «Российская медицинская академия непрерывного профессионального образования» Минздрава России, Москва, Россия Сазанова Юлия Олеговна - аспирант кафедры педиатрии с курсом поликлинической педиатрии им. академика Г.Н. Сперанского ФГБОУ ДПО «Российская медицинская академия непрерывного профессионального образования» Минздрава Россия, Москва, Россия

Дедикова Ольга Валерьевна - клинический ординатор кафедры педиатрии с курсом поликлинической педиатрии им. академика Г.Н. Сперанского ФГБОУ ДПО «Российская медицинская академия непрерывного профессионального образования» Минздрава России, Москва, Россия

Кольцов Константин Анатольевич - врач-педиатр, кафедра педиатрии с курсом поликлинической педиатрии им. академика Г.Н. Сперанского ФГБОУ ДПО «Российская медицинская академия непрерывного профессионального образования» Минздрава России, Москва, Россия 